University of Nebraska - Lincoln

DigitalCommons@University of Nebraska - Lincoln

Agronomy \& Horticulture - Faculty Publications

Agronomy and Horticulture Department

4-16-2008

\title{
Active Sensor Reflectance Measurements of Corn Nitrogen Status and Yield Potential
}

\author{
Fernando Solari \\ Monsanto, Pergamino, Buenos Aires, Argentina \\ John Shanahan \\ USDA-ARS
}

Richard B. Ferguson

University of Nebraska-Lincoln, rferguson1@unl.edu

James S. Schepers

University of Nebraska-Lincoln, james.schepers@gmail.com

Anatoly A. Gitelson

University of Nebraska-Lincoln, agitelson2@unl.edu

Follow this and additional works at: https://digitalcommons.unl.edu/agronomyfacpub

Part of the Plant Sciences Commons

Solari, Fernando; Shanahan, John; Ferguson, Richard B.; Schepers, James S.; and Gitelson, Anatoly A., "Active Sensor Reflectance Measurements of Corn Nitrogen Status and Yield Potential" (2008). Agronomy \& Horticulture -- Faculty Publications. 117.

https://digitalcommons.unl.edu/agronomyfacpub/117

This Article is brought to you for free and open access by the Agronomy and Horticulture Department at DigitalCommons@University of Nebraska - Lincoln. It has been accepted for inclusion in Agronomy \& Horticulture -Faculty Publications by an authorized administrator of DigitalCommons@University of Nebraska - Lincoln. 


\title{
Active Sensor Reflectance Measurements of Corn Nitrogen Status and Yield Potential
}

\author{
Fernando Solari, John Shanahan,* Richard Ferguson, James Schepers, \\ and Anatoly Gitelson
}

\begin{abstract}
Active sensor reflectance assessments of corn (Zea mays L.) canopy $\mathrm{N}$ status are advocated to direct variable $\mathrm{N}$ applications and improve $\mathrm{N}$ use efficiency (NUE). Our goals were to determine: (i) growth stage and (ii) sensor vegetation index with greatest sensitivity in assessing $\mathrm{N}$ status and grain yield. Variable crop $\mathrm{N}$ was generated by supplying $\mathrm{N}$ at different amounts and times in three field studies. Chlorophyll meter (CM) and sensor data were gathered at two vegetative (V11 and V15) and two reproductive (R1 and R3) growth stages, using the Crop Circle sensor that measures reflectance in visible (590 $\mathrm{nm}$ ) and near infrared (NIR) $(880 \mathrm{~nm})$ bands. Sensor data were converted to the normalized difference vegetation index $\left(\mathrm{NDVI}_{590}\right)$ and chlorophyll index $\left(\mathrm{CI}_{590}\right)$ values. Grain yields were also determined. Sensor indices were more highly correlated with $\mathrm{CM}$ readings for vegetative vs. reproductive growth ( $r^{2}$ of 0.85 vs. 0.55$)$. The $\mathrm{CM}_{\text {vs. }} \mathrm{CI}_{590}$ slope was over twice the $\mathrm{NDVI}_{590}$ slope value, indicating $\mathrm{CI}_{590}$ was more sensitive than $\mathrm{NDVI}_{590}$ in assessing canopy greenness. Indices did not differ in ability to distinguish yield variation. Results indicate sensor $\mathrm{CI}_{590}$ values collected during vegetative grow th are best suited to direct variable $\mathrm{N}$ applications.
\end{abstract}

$\mathrm{C}$ URRENT N MANAGEMENT SYSTEMS for corn have resulted in low NUE, with fertilizer $\mathrm{N}$ recovery averaging only around 33\% (Raun and Johnson, 1999). This has led to environmental contamination and concerns regarding use of $\mathrm{N}$ fertilizers. Development of alternative management strategies will be vital to sustaining cereal production systems. The major causes for low NUE with standard N management practices are: (i) poor synchrony between soil $\mathrm{N}$ supply and crop demand (Raun and Johnson, 1999; Cassman et al., 2002), (ii) field uniform $\mathrm{N}$ applications to spatially variable landscapes having spatially variable crop $\mathrm{N}$ need (Mamo et al., 2003; Scharf et al., 2005), and (iii) failure to account for temporal variability and the influence of weather on mid-season $\mathrm{N}$ needs (Lory and Scharf, 2003). To address concerns of spatial variability and synchronizing $\mathrm{N}$ inputs, Shanahan et al. (2008) advocated using active sensor reflectance measurements of corn canopy $\mathrm{N}$ status to guide spatially variable $\mathrm{N}$ applications, beginning at early vegetative growth (V8) (Ritchie et al., 1997) and proceeding through silking (R1). Active sensor is used in this discussion to refer to recently developed sensors that generate their

F. Solari, Monsanto, Pergamino, Buenos Aires, Argentina; J. Shanahan and J. Schepers, USDA-ARS, Lincoln, NE 68583; R. Ferguson, Dep. of Agronomy \& Hortic., Univ. of Nebraska, Lincoln, NE 68583; A. Gitelson, School of Nat. Resources, Univ. of Nebraska, Lincoln, NE 68583. Mention of commercial products and organizations in this article is solely to provide specific information. It does not constitute endorsement by USDA-ARS over other products and organizations not mentioned. The USDA-ARS is an equal opportunity/affirmative action employer and all agency services are available without discrimination. Received 12 July 2007. ${ }^{*}$ Corresponding author (John.Shanahan@ars.usda.gov).

Published in Agron. J. 100:571-579 (2008). doi:10.2134/agronj2007.0244

Copyright $\odot 2008$ by the American Society of Agronomy, 677 South Segoe Road, Madison, WI 53711. All rights reserved. No part of this periodical may be reproduced or transmitted in any form or by any means, electronic or mechanical, including photocopying, recording, or any information storage and retrieval system, without permission in writing from the publisher. own light source vs. passive sensor systems that utilize natural sunlight to function. Little research has been conducted to date on using active sensors in corn $\mathrm{N}$ management. Hence, it is necessary to substantiate that active sensors can reliably assess corn $\mathrm{N}$ status before further advocating their use.

The SPAD CM manufactured by Minolta (Konica Minolta, Hong Kong) is a handheld device that clamps to a leaf and measures light transmittance in the red $(650 \mathrm{~nm})$ and NIR $(940 \mathrm{~nm})$ spectral bands. Its readings are strongly correlated with actual leaf chlorophyll levels as determined by biochemical methods (Markwell et al., 1995). Because of this ability to rapidly assess chlorophyll content, the CM has been widely studied as a tool for improving $\mathrm{N}$ fertilizer management. Work by Blackmer et al. (1993) and Blackmer and Schepers (1994, 1995) has shown that CM assessments can be used to monitor corn $\mathrm{N}$ status for more efficient fertilizer $\mathrm{N}$ application. They observed $\mathrm{N}$ stress and yield losses whenever CM readings for managed areas declined below $95 \%$ of readings for corn receiving adequate to excess $\mathrm{N}$ at planting time, and suggested the 95\% sufficiency index (SI) value would be a reasonable trigger point to apply N. Varvel et al. (1997) confirmed these findings in a study involving $\mathrm{N}$ applications directed by $\mathrm{CM}$ assessments from V8 through silking. Likewise, Scharf et al. (2006), Hawkins et al. (2007), and Varvel et al. (2007) also concluded that CM readings were a good predictor of corn yield response to $\mathrm{N}$ over a wide array of growth stages, soils, geography, landscapes, environments, hybrids, and management schemes, and would be effective in making $\mathrm{N}$-fertilizer decisions. Together, the cited research has established that (i) monitoring the plant during vegetative growth (V6 to silking) to ascertain N status can be used as a means to maintain sufficient $\mathrm{N}$ for the crop

Abbreviations: CI, chlorophyll index; CM, chlorophyll meter; GDD, growing degree days; MSEA, Management Systems Evaluation Area; NDVI, normalized difference vegetation index; NIR, near infrared; NUE, nitrogen use efficiency; SEq, sensitivity equivalent; SI, sufficiency index; TSAVI, transformed soiladjusted vegetative index; VIS, visible. 
and (ii) yields can be maintained with less $\mathrm{N}$ than is normally used with single preplant applications. While managing large fields using this approach is problematic due to difficulty in obtaining adequate spatial data, it opens the door for advancement of active sensor technologies suitable for field-scale situations from which uniform $\mathrm{N}$ management can be replaced by crop evaluation and $\mathrm{N}$ application (Shanahan et al., 2008).

Remote sensing, using passive sensor systems (imagery or spectral radiometers), has long been advocated as a way to characterize spatial variability in fields (Bhatti et al., 1991). The simple ratio of NIR to red reflectance was found to be related to leaf area index (LAI) (Jordan, 1969) and was one of the first indices used for quantifying vegetation in remote sensing scenes. Rouse et al. (1974) later proposed the NDVI, where NDVI = (NIR - Red $) /($ NIR + Red $)$, and this index has become widely adopted. Nevertheless, concern for using NDVI to assess canopies with incomplete closure and/or exposed soil prompted some researchers (Huete, 1988; Rondeaux et al., 1996; Baret et al., 1989) to develop alternative indices (i.e., soil-adjusted vegetative index, or transformed soil-adjusted vegetative index (TSAVI) designed to minimize soil background effects. Shanahan et al. (2001) found the TSAVI equation to be no better than the NDVI in detecting corn canopy variation for early season images with soil exposure. Besides soil background effects, it is also important to consider the amount of vegetation present during image acquisition to use the most appropriate vegetation indices with the greatest sensitivity in assessing canopy variability. To enhance sensitivity of NDVI to moderate-to-high vegetation fraction as LAI exceeds two, the green NDVI [green NDVI $=(\mathrm{NIR}-$ Green $) /(\mathrm{NIR}+$ Green $)$ ] was proposed by Gitelson et al. (1996). Shanahan et al. (2001) using high resolution digital imagery found that green NDVI was more sensitive than NDVI in discerning variability in corn canopies as the season progressed and vegetation levels increased. More recently, research by Gitelson et al. $(2003,2005)$ revealed that the $\mathrm{CI}$, where $\mathrm{CI}=(\mathrm{NIR} / \mathrm{Green})-1$, was even more sensitive than green NDVI in assessing total canopy chlorophyll content or greenness under moderate-to-high crop biomass.

Because of soil background effects and cost and reliability of imagery acquisition, researchers have explored alternative remote sensing techniques for obtaining information on crop $\mathrm{N}$ status, using canopy sensors. Using a four-band passive sensor system (blue, green, red and NIR), Shanahan et al. (2003) were able to show that sensor-determined green NDVI values could potentially be used to direct in-season $\mathrm{N}$ applications. However, because passive sensor systems rely on natural sunlight, their effectiveness for assessing canopy $\mathrm{N}$ status is limited by numerous factors including intermittent cloud cover, narrow time window for operation (around solar noon), and bidirectional reflection issues associated with solar angle. Alternatively, Raun et al. (2002) and Mullen et al. (2003) demonstrated that canopy assessments using the GreenSeeker (NTech Industries, Ukiah, CA) active sensor, which generates its own source of modulated light in the red $(\sim 650 \mathrm{~nm})$ and NIR $(\sim 70 \mathrm{~nm})$ bands to calculate NDVI, could be used to direct variable rate $\mathrm{N}$ applications to wheat and improve fertilizer NUE. Active sensors are not subject to the previously mentioned limitations associated with passive sensors.
Despite the positive results obtained using the GreenSeeker on wheat, little work has been conducted to date using active sensors to assess corn $\mathrm{N}$ requirement during the in-season application window (V8 through R1 growth stages) proposed by Shanahan et al. (2008). Using the GreenSeeker to assess canopy $\mathrm{N}$ status during this window is problematic, because of the high vegetation fraction normally present during this time and the associated problems of using red light to assess canopy $\mathrm{N}$ status (Gitelson et al., 1996). For this reason, we chose to work with the Crop Circle ACS-210 active sensor manufactured by Holland Scientific (Lincoln, NE) as a means of assessing corn N status. Because the Crop Circle sensor (Holland et al., 2004) measures canopy reflectance in the NIR band (centered at 880 $\mathrm{nm}$ ) and the VIS band (centered at $590 \mathrm{~nm}$, near green reflectance peak, Gitelson et al., 1996), it is not subject to the same restrictions as the GreenSeeker for assessing corn canopies with increased green biomass.

The previously cited research results showed that besides using sensors that possess appropriate spectral bands, it is also critical to select the appropriate growth stage(s) for acquiring data and use the most suitable vegetation indices with the greatest capacity and/or sensitivity for assessing canopy greenness. Because these results were obtained using passive sensor systems, we were interested in determining if similar principles would be applicable when using active sensors like the Crop Circle. Hence, the goals of this research were to determine the most appropriate (i) growth stage (among V11, V15, R1 and R3 stages) and (ii) sensor-determined vegetation index $\left(\mathrm{NDVI}_{590}\right.$ vs. $\mathrm{CI}_{590}$ ) with the greatest sensitivity in assessing corn canopy $\mathrm{N}$ status along with grain yield.

\section{MATERIALS AND METHODS}

\section{Field Design and Experimental Treatments}

To address our study objectives, field plots were established at three sites during the 2005 growing season, where fertilizer $\mathrm{N}$ was applied in different amounts and at different times in an attempt to generate canopies with varying $\mathrm{N}$ status and yield potential. All three studies were conducted within the vicinity of the Nebraska Management Systems Evaluation Area (MSEA) project near Shelton, NE ( $40^{\circ} 45^{\prime} 01^{\prime \prime} \mathrm{N}, 98^{\circ} 46^{\prime} 01^{\prime \prime} \mathrm{W}$, elevation of $620 \mathrm{~m}$ above sea level), with two studies located on fields under a linear sprinkler irrigation system (designated as MSEA 1 and MSEA 2) and the third on a farmer's field under center pivot irrigation within $1 \mathrm{~km}$ (designated MSEA 3). The soil at all three sites was a Hord silt loam (fine-silty, mixed mesic Pachic Haplustoll, 0-1\% slope). All studies were conducted on fields that had been under monoculture corn for the previous $15 \mathrm{yr}$. The crop was seeded on 9 May 2005 at the MSEA 1 and MSEA 2 sites and 25 Apr. 2005 on the MSEA 3 field at a target density of 74,000 seeds ha ${ }^{-1}$. To satisfy the $\mathrm{P}$ requirement at all sites, liquid ammonium phosphate fertilizer $(10-34-0, \mathrm{~N}-\mathrm{P}-\mathrm{K})$ was applied at the rate of $94 \mathrm{~L} \mathrm{ha}^{-1}$ beneath the seed at planting, providing approximately $12 \mathrm{~kg}$ $\mathrm{ha}^{-1} \mathrm{~N}$ and $18 \mathrm{~kg} \mathrm{ha}^{-1} \mathrm{P}$. The crop received irrigation throughout the growing season according to established irrigation scheduling principles. No $\mathrm{N}$ was supplied in the irrigation water at the MSEA 1 and 2 sites; whereas at the MSEA 3 site, a total of $56 \mathrm{~kg} \mathrm{ha}^{-1} \mathrm{~N}$ was supplied through the irrigation water during the entire growing season. Before planting, at least 10 
soil cores to a depth of $0.9 \mathrm{~m}$, in $0.3-\mathrm{m}$ increments, were collected and composited from the study area at each site and analyzed to assess residual $\mathrm{N}$ ( $0 \mathrm{~N}$ check plots were sampled at the long-term MSEA 1 site). Weed control at all sites was accomplished through a combination of cultivation and herbicide application.

Climatological data were recorded using an automated weather station (High Plains Climate Center Network, University of Nebraska) located on the MSEA site. Since our goal was to collect CM and sensor data at four specific crop stages, we recorded phenological data according to Ritchie et al. (1997) beginning on 1 June and continued weekly until physiological maturity. Thermal time (growing degree days, GDD) was also logged and accumulated for each site beginning from the planting date. Thermal time computations were made using Method II of McMaster and Wilhelm (1997), where daily maximum $\left(\mathrm{T}_{\text {MAX }}\right)$ and minimum $\left(\mathrm{T}_{\text {MIN }}\right)$ temperatures, a base $\left(\mathrm{T}_{\mathrm{BASE}}\right)$ of $10^{\circ} \mathrm{C}$, and a threshold $\left(\mathrm{T}_{\mathrm{THRESH}}\right)$ of $30^{\circ} \mathrm{C}$ are used. Then GDD $=\left[\left(\mathrm{T}_{\mathrm{MAX}}+\mathrm{T}_{\mathrm{MIN}}\right) / 2\right]-\mathrm{T}_{\mathrm{BASE}}$, with the following conditions: If $\mathrm{T}_{\text {MAX }}<\mathrm{T}_{\text {BASE}}$, then $\mathrm{T}_{\text {MAX }}=\mathrm{T}_{\text {BASE }}$, if $\mathrm{T}_{\text {MIN }}<\mathrm{T}_{\text {BASE }}$, then $\mathrm{T}_{\text {MIN }}=\mathrm{T}_{\mathrm{BASE}}$, if $\mathrm{T}_{\text {MIN }}>\mathrm{T}_{\text {THRESH }}$, then $\mathrm{T}_{\text {MIN }}=\mathrm{T}_{\text {THRESH }}$, and if $\mathrm{T}_{\text {MAX }}>$ $\mathrm{T}_{\text {THRESH }}$, then $\mathrm{T}_{\text {MAX }}=\mathrm{T}_{\text {THRESH }}$. These substitutions are made before calculating $\left(\mathrm{T}_{\mathrm{MAX}}+\mathrm{T}_{\mathrm{MIN}}\right) / 2$.

The study at the MSEA 1 site was part of an ongoing study initiated in 1991 (Varvel et al., 1997) involving treatments consisting of a factorial combination of two cropping schemes (monoculture corn and soybean-corn), four corn hybrids, and six $\mathrm{N}$ regimes, which were five $\mathrm{N}$ rates $(0,50,100,150$, and $200 \mathrm{~kg} \mathrm{~N} \mathrm{ha}^{-1}$ ) at planting and one as needed applied in-season using CM assessments (Varvel et al., 1997). A split-split-split plot treatment design within a randomized complete block experiment with four replications was used. Cropping systems were assigned as the main plots, corn hybrids as the subplots, and $\mathrm{N}$ fertilizer regimes as the sub-subplots. All phases of the monoculture corn and soybean-corn systems appeared each year starting with the 1991 growing season. Individual plot dimensions were 7.3 by $15.2 \mathrm{~m}$, consisting of eight $0.91-\mathrm{m}$ rows planted in an east-west direction. For this study, CM and sensor data were collected from a subset of the treatments, including treatments grown under monoculture corn using two (Pioneer Brand '33V15' and '31N27') of the four hybrids and the five at-planting $\mathrm{N}$ regimes. Using the monoculture corn provided the greatest range in $\mathrm{N}$ availability conditions and the two hybrids selected provided a contrast in canopy architecture, with 33V15 being upright and 31N27 being planophile.

At the MSEA 2 and MSEA 3 sites, the field design employed a randomized complete block with three replications and treatment factors arranged as split-split plots. Factors under study were at-planting $\mathrm{N}$ application rates of $0,45,90$, or 270 $\mathrm{kg} \mathrm{ha}^{-1}$, time of in-season $\mathrm{N}$ application (V11 or V15), and in-season $\mathrm{N}$ rates of $0,45,90,135$, or $180 \mathrm{~kg} \mathrm{ha}^{-1}$. In-season $\mathrm{N}$ application time was assigned to whole plots, at-planting $\mathrm{N}$ application rates to subplots, and in-season $\mathrm{N}$ application rates to sub-subplots. The $270 \mathrm{~kg} \mathrm{ha}^{-1}$ at-planting $\mathrm{N}$ rate served as the adequately fertilized $\mathrm{N}$ reference treatment, and thus was not included in the factorial combination with other in-season $\mathrm{N}$ levels. Plot dimensions at both sites were 7.3 by $15.2 \mathrm{~m}$, consisting of 8 rows ( $0.91 \mathrm{~m}$ apart). Pioneer Brand '33G30' was planted at the MSEA 2 site and ' 34 N42' at the MSEA 3 site. The $\mathrm{N}$ treatments were applied at the appropriate times as a solution of urea and ammonium nitrate containing $28 \% \mathrm{~N}$.

\section{Description of Active Sensor System}

The active sensor used in our work was the Crop Circle model ACS-210 of Holland Scientific (Lincoln, NE) and it measures canopy reflectance at two wavebands in the VIS centered at $590 \pm 5.5 \mathrm{~nm}\left(\mathrm{VIS}_{590}\right)$ and NIR centered at $880 \pm 10$ $\mathrm{nm}\left(\mathrm{NIR}_{880}\right)$. The $\mathrm{VIS}_{590}$ band was selected in constructing the Crop Circle sensor in lieu of the green band ( 560 $\mathrm{nm}$ ) studied by Gitelson et al. (2003 and 2005) because the electro-optical characteristics for various combinations of commercially available photodiodes and filters provided better measurement performance characteristics in the 590-nm band than in the $560-\mathrm{nm}$ band (K. Holland, personal communication, February 2005). However, this is not problematic because the sensitivity of reflectance to chlorophyll content remains high and relatively constant in a wide spectral range from 530 through $600 \mathrm{~nm}$ (Gitelson et al., 1996). The sensor generates its own source of modulated light (pulsed at $\sim 40,000 \mathrm{~Hz}$ ) using a single bank of polychromatic diodes with a field of view of $32^{\circ}$ by $6^{\circ}$. Photodetection of modulated light reflected from the crop canopy back to the sensor is accomplished with two banks of silicon photodiodes located in the sensor, sensitive in a spectral range of 320 to $1100 \mathrm{~nm}$, with one bank filtered to accept VIS $_{590}$ and one the NIR $_{880}$ band.

Sensor readings were collected at 10 times per second, so each recorded sensor value represents the average of about 4000 individual sensor readings. Photodetection of ambient light by the sensor is rejected at solar irradiance levels up to $400 \mathrm{~W}$ $\mathrm{m}^{-2}$. The sensor was calibrated using a $20 \%$ universal reflectance panel with the sensor placed in the nadir position above the panel. Sensor amplifiers for each waveband were adjusted so that a value of 1.0 was obtained from the $20 \%$ reflectance panel at $0.9 \mathrm{~m}$ from the target. Final output from the sensor is a pseudo-reflectance value for both bands that allows for the calculation of various vegetation indices.

\section{Acquisition of Sensor Reflectance Data and Conversion to Vegetation Indices}

Sensor readings were collected at four crop growth stages, two vegetative (V11 and V15) and two reproductive (R1 and R3). To accomplish this task, the sensor was mounted on an adjustable height boom on a high clearance vehicle to maintain the sensor at a specified height above the canopy at each growth stage. The sensor was positioned directly over a center plot row in the nadir view at a distance of approximately $0.8 \mathrm{~m}$ above the crop canopy for plots receiving the highest $\mathrm{N}$ rate, producing a sensor footprint of approximately 0.1 by $0.5 \mathrm{~m}$. The long dimension of this footprint was oriented perpendicular to the row direction. This sensor position was determined to be the most optimal, of several positions evaluated, for sensing canopy greenness in previous work by Solari (2006). The sensor and a DGPS receiver (model 16A, Garmin International, Olathe, $\mathrm{KS}$ ) were interfaced to a computer via a serial hub and readings were logged (sensor and spatial coordinates) as the vehicle traveled through the plots at 6 to $7 \mathrm{~km} \mathrm{~h}^{-1}$, acquiring approximately 200 readings per plot. Data were imported into a GIS 


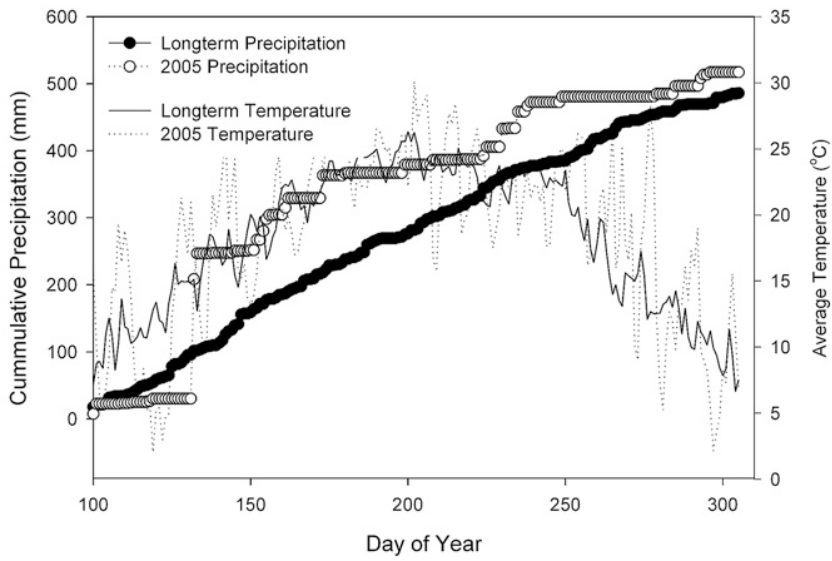

Fig. I. Cumulative precipitation and average temperatures for the $\mathbf{2 0 0 5}$ growing season (April-October) vs. long-term averages for the MSEA site near Shelton, NE.

for analysis. An area of interest was produced for each plot that corresponded to the plot boundary minus a $1.0-\mathrm{m}$ buffer area adjacent to plot alleyways. Sensor readings were extracted from the area of interest to avoid border effects in each plot. The VIS 590 and $\mathrm{NIR}_{880}$ bands from individual sensor readings were converted to two different vegetation indices and averaged to produce one index value for each plot. The two indices calculated were the $\mathrm{NDVI}_{590}$ and chlorophyll index $\left(\mathrm{CI}_{590}\right)$, using the following equations and the appropriate band reflectance values: $\mathrm{NDVI}_{590}=\left(\mathrm{NIR}_{880}-\mathrm{VIS}_{590}\right) /\left(\mathrm{NIR}_{880}+\mathrm{VIS}_{590}\right)$, $\mathrm{CI}_{590}=\left(\mathrm{NIR}_{880} / \mathrm{VIS}_{590}\right)-1$.

Because of the close relationship between green reflectance around $560 \mathrm{~nm}$ and reflectance at $590 \mathrm{~nm}$ (Gitelson et al., 2003, 2005), both vegetation indices tested in this study, $\mathrm{NDVI}_{590}$ and $\mathrm{CI}_{590}$, are proxy of green NDVI and $\mathrm{CI}_{\text {green' }}$, respectively.

\section{Leaf Chlorophyll Content Assessment}

Leaf chlorophyll content among treatments was also assessed with the Minolta SPAD CM model 502 (Spectrum Technologies, Plainfield, IL) according to the methodology of Blackmer and Schepers (1995) on the same day sensor readings were acquired. Before the silking growth stage, readings were collected from the most recent fully expanded leaf (visible collar); after silking, the ear leaf was sampled. Measurements were taken midway between the leaf tip and base and midway between the margin and the midrib from 30 representative plants selected from the row sensor readings acquired, and individual readings were averaged to produce one value per plot. Plants unusually close together or far apart or those that were damaged were not sampled.

\section{Plant Counts and Grain Yields}

To estimate plant density variability, final plant counts were acquired just before harvest using a $2-\mathrm{m}$ section of the row from which sensor readings were acquired within each plot. To determine grain yields, the center three rows of each plot were machine harvested and a subsample was retained to ascertain grain moisture content. Grain yields were adjusted to a constant moisture basis of $155 \mathrm{~g} \mathrm{~kg}^{-1}$ water.

\section{Statistical Analysis Procedures}

Plant density variability at each site was determined using the CV statistic. The CV was also used to assess within plot variability in sensor readings converted to the vegetation indices. To account for the effect of differences among hybrids, sensor and CM readings were normalized within replicates and hybrid for each growth stage using readings from the highest at-planting $\mathrm{N}$ rate as the denominator (Schepers et al., 1992; Schepers, 1994; Shapiro et al., 2006). Likewise, grain yields were normalized using similar procedures. Absolute grain yield, vegetation index, and CM data were analyzed via ANOVA with a mixed model, using the SAS PROC MIXED procedure (Littel et al., 1996). For yield data, hybrids and $\mathrm{N}$ treatments were considered fixed effects and blocks random effects. For the vegetation indices and CM data, the analysis was the same except sensor collection dates for the four different growth stages were included in the model and considered as repeated observations. Regression analysis (using SAS PROC REG) was used to determine if relationships between the different vegetation indices and their respective $\mathrm{CM}$ and grain yield values existed for each growth stage and study site, testing for both linear and quadratic components using coefficient of determination $\left(r^{2}\right)$ and $\mathrm{F}$ tests as preliminary criterion. To estimate the sensitivity of each vegetation index to change in $\mathrm{CM}$ reading, the slope for each relationship was first determined and then the sensitivity equivalent (SEq) was calculated (SEq = slope/ RMSE) according to Vina and Gitelson (2005), using slope and RMSE values for each relationship. Because SEq incorporates both slope and RMSE (a measure of deviation from regression), it provides a better assessment of differences in ability of indices to assess canopy variation (Vina and Gitelson, 2005).

\section{RESULTS AND DISCUSSION Climatological Conditions}

Temperatures for 2005 were near the long-term average for this location (Fig. 1), while accumulated precipitation was characterized by a significant early season event that occurred on 11 May when a total of $215 \mathrm{~mm}$ of rainfall fell. The remainder of the season provided relatively average weather conditions. The early-season precipitation event resulted in soil crusting and problems associated with plant stand establishment at the MSEA 2 site, as evidenced by CVs of plant density at each site. While average plant densities did not differ greatly among the three sites (mean of 70,600,71,500, and 71,900 plants ha ${ }^{-1}$ for MSEA 1,2, and 3 sites, respectively), the CV for plant densities was $17 \%$ at the MSEA 2 site compared with $8.5 \%$ at MSEA 1 and $6.7 \%$ at MSEA 3 sites. Perhaps the lower yields observed at the MSEA 2 site vs. the MSEA 1 and 3 sites (Fig. 2-4) were related with the more erratic plant densities at this site vs. the more uniform plant densities at the latter two sites. Previous research (Liu et al., 2004; Andrade and Abbate, 2005) suggested that more variable plant densities may contribute to lower yields.

\section{Nitrogen Effects on Grain Yields}

Residual soil nitrate $\mathrm{N}$ levels ( $0.9 \mathrm{~m}$ profile) before planting were 10, 28, and $15 \mathrm{~kg} \mathrm{~N} \mathrm{ha}^{-1}$ at the MSEA 1, 2, and 3 sites, respectively, suggesting conditions were favorable for $\mathrm{N}$ responses at all three sites. At the MSEA 1 site, $\mathrm{N}$ application 


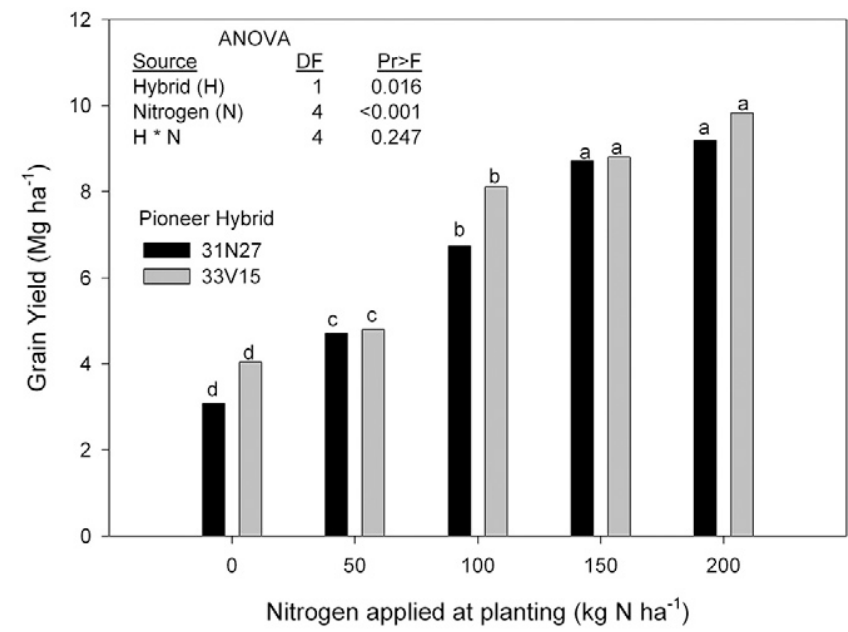

Fig. 2. Average grain yield responses of two corn hybrids (Pioneer brand hybrid 3 IN27 and 33VI5) receiving five atplanting $\mathbf{N}$ levels at the MSEA I site near Shelton, NE, in 2005. The ANOVA, depicting treatment effects on grain yield, is also shown. Grain yield means followed by the same letter are not significantly different at the $\boldsymbol{P} \leq \mathbf{0 . 0 5}$ level as determined by the LSD test.

at planting resulted in a more than threefold increase in grain yields from 3 to $10 \mathrm{Mg} \mathrm{ha}^{-1}$, exhibiting a curvilinear response (quadratic effect significant at $P \leq 0.01$ ) to varying $\mathrm{N}$ (Fig. 2). The ANOVA revealed that the hybrid $\times \mathrm{N}$ interaction was nonsignificant, indicating hybrids responded similarly to $\mathrm{N}$. These results are similar to previous observations (Varvel et al., 1997; Shanahan et al., 2001) using the same treatments and plots. Effects of $\mathrm{N}$ application on grain yields were also observed at the MSEA 2 (Table 1 and Fig. 3) and MSEA 3 (Table 1 and Fig. 4) sites, although the analyses revealed that the magnitude of the $\mathrm{N}$ responses varied across the two sites. For example, at the MSEA 2 site, yields exhibited a linear increase of around $15 \%$ with additional in-season $\mathrm{N}$ (Fig. 3), while at the MSEA 3 site, yields displayed a curvilinear increased of around $25 \%$ with additional $\mathrm{N}$. The lower $\mathrm{N}$ response at the MSEA 2 site was likely due to the higher residual soil N levels and more variable plant densities at the MSEA 2 site, limiting the potential for yield response to applied N. In summary, our imposed $\mathrm{N}$ treatments created significant variation in grain yields, particularly at the MSEA 1 and 3 sites.

\section{Nitrogen Effects on Leaf Chlorophyll and Sensor-Determined Vegetation Indices}

The ANOVA for CM measurements and sensor-determined vegetation indices $\left(\mathrm{NDVI}_{590}\right.$ and $\left.\mathrm{CI}_{590}\right)$ at the three sites (Tables 2 and 3) demonstrated that $\mathrm{N}$ treatments affected leaf chlorophyll levels and sensor readings. These analyses revealed that leaf greenness measurements were also affected by other factors including hybrid (MSEA 1 site), growth stage, and the interaction of N levels with growth stage, which is similar to the results of Shanahan et al. (2001) or Shanahan et al. (2003) using imagery or passive sensors. Hence all readings were normalized as previously described in the methods. While this normalization process eliminated some treatment effects (i.e., hybrids at the MSEA 1 site), the effect of $\mathrm{N}$ was maintained for all measured variables and all locations (data not shown). In summary, the imposed $\mathrm{N}$ treatments created significant and

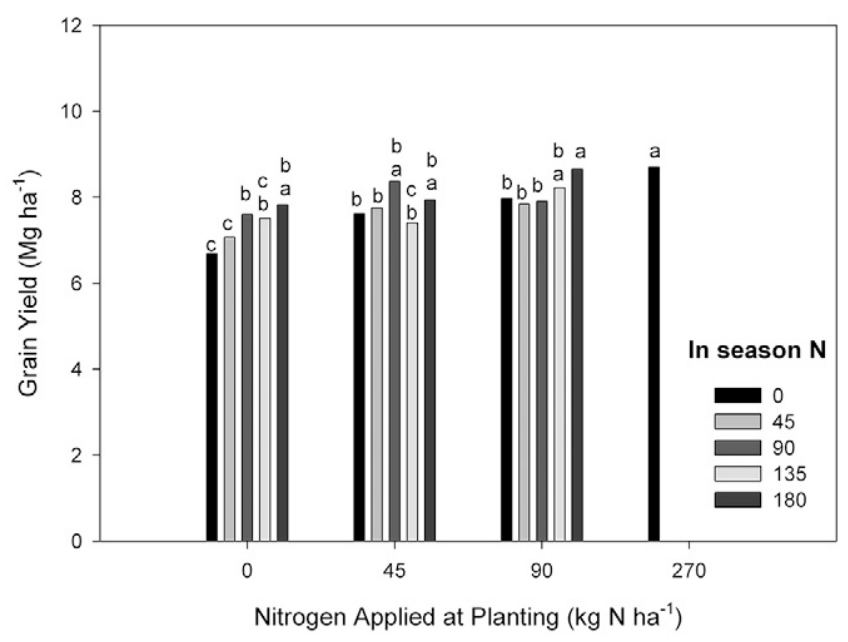

Fig. 3. Average grain yield responses of five in-season $\mathbf{N}$ application levels (averaged across VII and VI5 application dates) and three at-planting $\mathbf{N}$ levels as well as the high $\mathbf{N}$ reference treatment $\left(270 \mathrm{~kg} \mathrm{ha}^{-1} \mathrm{~N}\right)$ at MSEA 2 site near Shelton, NE, in 2005 . Grain yield means followed by the same letter are not significantly different at the $\boldsymbol{P} \leq \mathbf{0 . 0 5}$ level as determined by the LSD test.

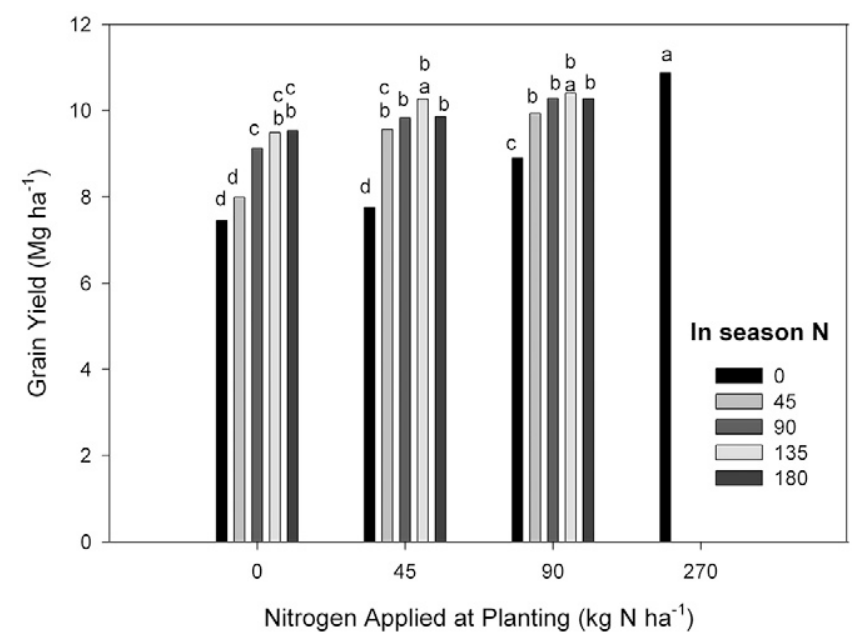

Fig. 4. Average grain yield responses of five in-season $\mathbf{N}$ application levels (averaged across VII and VI5 application dates) and three at-planting $\mathbf{N}$ levels as well as the high $\mathbf{N}$ reference treatment $\left(270 \mathrm{~kg} \mathrm{ha}^{-1} \mathrm{~N}\right)$ at MSEA 3 site near Shelton, NE, in 2005. Grain yield means followed by the same letter are not significantly different at the $\boldsymbol{P} \leq \mathbf{0 . 0 5}$ level as determined by the LSD test.

Table I. Analysis of variance of yield responses from corn receiving five $\mathbf{N}$ in-season (NIS) levels, applied at two times (VII and VI5) in-season (TIN), and four at-planting N levels (NAP) during the 2005 growing season at the MSEA 2 and MSEA 3 sites near Shelton, NE.

\begin{tabular}{lrrr}
\hline \multicolumn{1}{c}{ Source of variation } & $\mathrm{df}$ & MSEA 2 & MSEA 3 \\
\cline { 3 - 4 } TIN & & 0.059 & 0.790 \\
NAP & $\mathrm{I}$ & $<>$. & \\
TIN $\times$ NAP & 3 & 0.001 & $<0.001$ \\
NIS & 3 & 0.009 & 0.286 \\
TIN $\times$ NIS & 4 & $<0.001$ \\
NAP $\times$ NIS & 4 & 0.040 & 0.894 \\
TIN $\times$ NAP $\times$ NIS & 8 & 0.038 & 0.621 \\
\hline
\end{tabular}


Table 2. Analysis of variance for chlorophyll meter readings (CM) and two vegetation indices ( $\mathrm{NDVI}_{590}$ normalized difference vegetation index; $\mathrm{Cl}_{590}$, chlorophyll index) calculated from active sensor readings collected on four growth stages (GS) for two corn hybrids receiving five at-planting $\mathbf{N}$ levels during 2005 at the MSEA I field near Shelton, NE.

\begin{tabular}{|c|c|c|c|c|}
\hline Source of variation & df & CM & $\mathrm{NDVI}_{590}$ & $\mathrm{Cl}_{590}$ \\
\hline & & & $-P>F-$ & \\
\hline Hybrid & I & $<0.001$ & $<0.001$ & $<0.001$ \\
\hline $\mathrm{N}$ & 4 & $<0.001$ & $<0.001$ & $<0.001$ \\
\hline Hybrid $\times \mathrm{N}$ & 4 & 0.828 & 0.642 & 0.552 \\
\hline GS & 3 & $<0.001$ & $<0.001$ & $<0.001$ \\
\hline Hybrid $\times$ GS & 4 & 0.015 & $<0.001$ & $<0.001$ \\
\hline$N \times G S$ & 16 & $<0.001$ & 0.001 & $<0.001$ \\
\hline Hybrid $\times \mathrm{N} \times \mathrm{GS}$ & 16 & 0.002 & 0.248 & 0.012 \\
\hline
\end{tabular}

consistent variation in relative yields, CM readings, and sensordetermined vegetation indices, allowing us to address our study objectives.

\section{Relationships between Vegetation Indices and Leaf Chlorophyll}

After establishing $\mathrm{N}$ treatments produced significant variation in CM and sensor-determined measures of canopy greenness, the extent of association between relative CM readings and relative values for the two vegetation indices $\left(\mathrm{NDVI}_{590}\right.$ and $\mathrm{CI}_{590}$ ) was determined using linear regression techniques. A significant $(P \leq 0.05)$ quadratic component was observed for only one growth stage and one location (MSEA 1 site). Therefore, only the linear aspects of these relations are presented (Table 4) and discussed. For the two vegetative growth stages (V11 and V15), significant linear relationships between relative $\mathrm{CM}$ readings and the two vegetation indices were observed at all three sites, although the $r^{2}$ values were much lower at the MSEA 2 site relative to the other two sites. While the $r^{2}$ values between CM readings and the vegetation indices were generally statistically significant for the reproductive

Table 3. Analysis of variance for chlorophyll meter (CM) assessments and two vegetation indices (NDVI ${ }_{590}$, normalized difference vegetation index; $\mathrm{Cl}_{590}$, chlorophyll index) calculated from active sensor data collected on four growth stages (GS) from corn receiving five $\mathbf{N}$ in-season (NIS) levels, applied at two times (VII and VI5) in-season (TIN), and four at-planting $N$ levels (NAP) during the 2005 growing season at the MSEA 2 and MSEA 3 sites near Shelton, NE.

\begin{tabular}{|c|c|c|c|c|c|c|c|}
\hline \multirow[b]{2}{*}{ Source of variation } & \multirow[b]{2}{*}{$\mathrm{df}$} & \multicolumn{3}{|c|}{ MSEA 2} & \multicolumn{3}{|c|}{ MSEA 3} \\
\hline & & CM & $\mathrm{NDVI}_{590}$ & $\mathrm{Cl}_{590}$ & CM & $\mathrm{NDVI}_{590}$ & $\mathrm{Cl}_{590}$ \\
\hline & & & & $-P=$ & & & \\
\hline TIN & I & $<0.001$ & 0.003 & 0.003 & 0.235 & 0.018 & 0.033 \\
\hline NAP & 3 & $<0.001$ & $<0.001$ & $<0.001$ & $<0.001$ & $<0.001$ & $<0.001$ \\
\hline TIN $\times$ NAP & 3 & 0.000 & 0.012 & 0.012 & 0.011 & 0.052 & 0.013 \\
\hline NIS & 4 & 0.292 & 0.975 & 0.975 & $<0.001$ & $<0.001$ & $<0.001$ \\
\hline TIN $\times$ NIS & 4 & 0.795 & 0.801 & 0.801 & 0.780 & 0.924 & 0.968 \\
\hline NAP $\times$ NIS & 8 & 0.523 & 0.833 & 0.833 & 0.254 & 0.447 & 0.575 \\
\hline $\mathrm{TIN} \times \mathrm{NAP} \times \mathrm{NIS}$ & 8 & 0.393 & 0.353 & 0.353 & 0.371 & 0.140 & 0.142 \\
\hline GS & 3 & $<0.001$ & $<0.001$ & $<0.001$ & $<0.001$ & $<0.001$ & $<0.001$ \\
\hline $\mathrm{TIN} \times \mathrm{GS}$ & 3 & $<0.001$ & $<0.001$ & $<0.001$ & 0.575 & 0.058 & 0.303 \\
\hline NAP $\times$ GS & 9 & 0.022 & $<0.001$ & $<0.001$ & 0.002 & $<0.001$ & $<0.001$ \\
\hline$T I N \times N A P \times G S$ & 9 & 0.054 & 0.006 & 0.006 & 0.406 & $<0.001$ & $<0.001$ \\
\hline $\mathrm{NIS} \times \mathrm{GS}$ & 12 & $0.47 \mathrm{I}$ & 0.998 & 0.998 & $<0.001$ & 0.079 & 0.273 \\
\hline TIN $\times$ NIS $\times$ GS & 12 & 0.377 & 0.997 & 0.997 & 0.747 & 0.961 & 0.992 \\
\hline $\mathrm{NAP} \times \mathrm{NIS} \times \mathrm{GS}$ & 24 & 0.947 & 0.924 & 0.924 & 0.999 & 0.839 & 0.821 \\
\hline$T I N \times N A P \times N I S \times G S$ & 24 & 0.970 & 0.978 & 0.978 & 0.990 & 0.854 & 0.941 \\
\hline
\end{tabular}

growth stages (R1 and R3), the $r^{2}$ values were noticeably lower for the reproductive (maximum $r^{2}$ of 0.55 ) than the vegetative growth stages (maximum $r^{2}$ of 0.85 ), except at MSEA 1 site. There was a complete lack of association between these variables during reproductive growth at the MSEA 2 site. Thus, the degree of association between CM readings and sensordetermined vegetation indices varied across both location and growth stage.

Given that CM readings were collected from individual leaves while vegetation indices were calculated from sensor readings acquired for the entire crop canopy, consisting of intermingled leaves of different ages and varying degrees of soil background exposure, it is not surprising associations varied across growth stages and sites. For example, prior research has shown that sizeable variation in color and $\mathrm{N}$ differences exist along the corn leaf blade (Piekielek and Fox, 1992; Chapman and Barreto, 1997; Drouet and Bonhomme, 1999) and up and down the plant (Drouet and Bonhomme, 1999). Additionally, crop growth stage and plant distribution affect the proportion of canopy and soil background visible to the remote sensing system, with increased soil exposure diminishing the ability of remote sensing to distinguish canopy variability (Shanahan et al., 2001). The average CV for within-plot sensor-determined $\mathrm{NDVI}_{590}$ values acquired at V11 for the MSEA 2 site was around $10 \%$ compared with a CV of around $6 \%$ for both MSEA 1 and MSEA 3 sites. Sensor readings continued to be more variable at the MSEA 2 site throughout the remainder of the growing season (data not shown). Thus, it seems very likely that the low associations observed between CM readings and vegetation indices at the MSEA 2 site were due to the more

\begin{tabular}{|c|c|c|}
\hline$\frac{\text { GS an }}{\text { MSEA I }}$ & $\mathrm{NDVI}_{590}$ & $\mathrm{Cl}_{590}$ \\
\hline \multicolumn{3}{|l|}{ MSEA I } \\
\hline VII (600) & $0.468 * *$ & $0.495 * *$ \\
\hline VI5 (700) & $0.784 * * *$ & $0.812^{* * *}$ \\
\hline RI (800) & $0.524 * *$ & $0.546 * *$ \\
\hline R3 (1000) & $0.33 * *$ & $0.663^{* * *}$ \\
\hline \multicolumn{3}{|l|}{ MSEA 2} \\
\hline VII (600) & $0.339 * * *$ & $0.339 * * *$ \\
\hline VI5 (700) & $0.364 * * *$ & $0.389 * * *$ \\
\hline RI (800) & NS $\ddagger$ & NS \\
\hline R3 (1000) & NS & NS \\
\hline \multicolumn{3}{|l|}{ MSEA 3} \\
\hline VII (600) & $0.725 * * *$ & $0.776 * * *$ \\
\hline VI5 (700) & $0.82 I^{* * *}$ & $0.847 * * *$ \\
\hline R2 (900) & $0.201 * * *$ & $0.185^{* * *}$ \\
\hline R3 (1000) & $0.042 *$ & $0.040 *$ \\
\hline \multicolumn{3}{|c|}{ * Significant at the 0.05 level. } \\
\hline \multicolumn{3}{|c|}{$* *$ Significant at the 0.01 level. } \\
\hline \multicolumn{3}{|c|}{$* * *$ Significant at the 0.0001 level. } \\
\hline \multicolumn{3}{|c|}{$\begin{array}{l}\text { † GS, growth stage according to Ritchie et al., 1997; GDD, } \\
\text { growing degree days according to McMaster and Wilhelm, } 1997\end{array}$} \\
\hline NS, nons & leve & \\
\hline
\end{tabular}




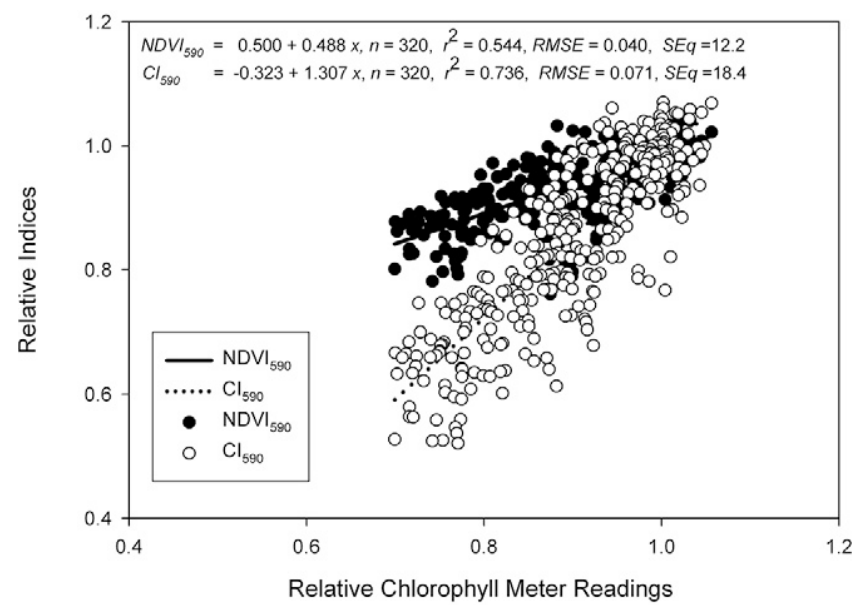

Fig. 5. Relationships between variation in relative chlorophyll meter (CM) readings and two sensor-determined vegetation indices (NDVI ${ }_{590}$, normalized difference vegetation index; $\mathrm{Cl}_{590}$, chlorophyll index) for data collected on two vegetative growth stages (VII and VI5) during the 2005 growing season at the MSEA I and 3 sites near Shelton, NE, for corn receiving varying amounts of applied $\mathbf{N}$. Other parameters provided include linear regression equation, sample number $(n)$, coefficient of determination $\left(r^{2}\right)$, RMSE, and sensitivity equivalent $(\mathrm{SEq}) ; \mathrm{SEq}=$ slope/RMSE.

variable plant densities. These results indicate that relatively uniform plant distributions are required for accurate sensor assessment of canopy $\mathrm{N}$ status.

The low associations observed between $\mathrm{CM}$ and sensor readings during reproductive grow th were not due to diminishing $\mathrm{N}$ effects on the crop at this time, since CM readings still showed significant variation among $\mathrm{N}$ treatments in canopy greenness for the two reproductive stages (data not shown). The low relationships were more likely due to presence of tassels existing on the plants during sensor readings, as Vina et al. (2004) have shown that tassels modify the spectral reflectance characteristics of the entire corn canopy, reducing the absorption of light especially in the visible region of the spectrum. Shanahan et al. (2001) observed a decline in the ability of digital imagery to discern variation in corn canopy $\mathrm{N}$ status around tasseling, which they speculated was due to tassel interference, and diminished over time as the tassel senesced. The low irradiance level provided by the sensor light source (less than $10 \mu$ $\mathrm{Wm}^{-2}$ to $1 \mathrm{~m} \mathrm{Wm}^{-2}$ ) may have also contributed to the poor associations during reproductive growth. For example, Solari (2006) found that readings obtained with the Crop Circle sensor can only penetrate 5 to 6 leaf levels in the corn canopy, and these findings were attributed to the low energy characteristics of the sensor light source. With the sensor positioned $\sim 0.8 \mathrm{~m}$ above the fully extended tassels of the crop, light emitting from the sensor is unable to reach the ear leaf, accessing instead only upper canopy leaves. Leaf area (Boedhram et al., 2001), chlorophyll content (Osaki et al., 1995a, 1995b), and leaf N (Drouet and Bonhomme, 1999) are not uniformly distributed up and down the canopy, but are rather concentrated around the ear leaf. Given these limitations, it is not surprising that $\mathrm{CM}$ and sensor readings were so poorly associated during reproductive growth. Whereas, during vegetative growth, CM and sensor readings were acquired from the uppermost expanded canopy leaves, and the sensor was more favorably positioned to assess $\mathrm{CM}$-sampled leaves, explaining why the two independent

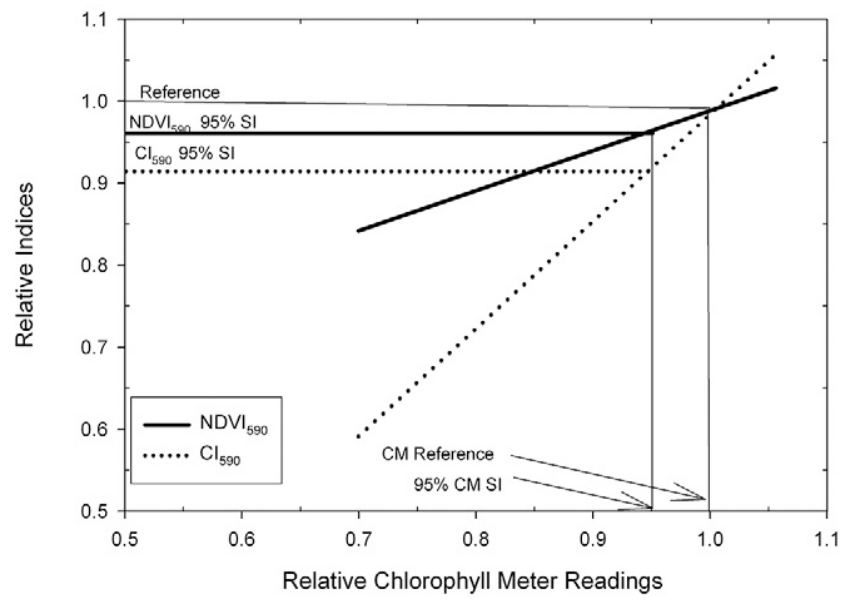

Fig. 6. Linear relationships between relative chlorophyll meter (CM) readings and two sensor-determined vegetation indices (NDVI ${ }_{590}$, normalized difference vegetation index; $\mathrm{Cl}_{590}$, chlorophyll index), as depicted in Fig. 5, along with reference and sufficiency index (SI) values for $\mathrm{CM}$ readings and corresponding vegetation indices.

assessments of canopy greenness were more highly associated. In summary, our results suggest that the Crop Circle sensor is better suited for assessing canopy $\mathrm{N}$ status during vegetative than reproductive growth. However, this should not present a significant problem for using the sensor to manage $\mathrm{N}$ in corn, since most applications would likely be made before tasseling (Shanahan et al., 2008). If it were deemed necessary to apply N after tasseling, sensors could potentially be positioned between rows at an oblique angle to avoid tassel interference.

After establishing that vegetation indices and $\mathrm{CM}$ readings were more highly associated during vegetative than reproductive growth, differences in sensitivity between the two indices in assessing canopy $\mathrm{N}$ status were determined. This was accomplished by comparing slope, $r^{2}$, and SEq values for each relationship (Fig. 5). These relationships were developed, using the MSEA 1 and 3 data, pooled across the two vegetative growth stages, and omitting MSEA 2 data due to low correlations (Table 4). The slope of the $\mathrm{CM}$ vs. $\mathrm{CI}_{590}$ relationship was more than twofold greater than that for the $\mathrm{NDVI}_{590}$ relationship (as determined by $t$ test). Likewise, the $r^{2}$ value was also markedly higher for the $\mathrm{CI}_{590}$ vs. the $\mathrm{NDVI}_{590}$ relationship. The $\mathrm{SEq}$ value was also higher for the $\mathrm{CI}_{590}$ relationship than the $\mathrm{NDVI}_{590}$ association. Collectively, these results imply that the $\mathrm{CI}_{590}$ was more sensitive than $\mathrm{NDVI}_{590}$ in discerning $\mathrm{CM}$-determined variation in canopy greenness. Differences in sensitivity between the two indices are further illustrated by comparing SI values for the two indices corresponding to the $95 \%$ SI value for CM readings (Fig. 6), a previously established threshold for identifying $\mathrm{N}$ stress in corn (Blackmer and Schepers, 1995). The corresponding SI threshold value for the $\mathrm{CI}_{590}$ was around $92 \%$ vs. $96 \%$ for $\mathrm{NDVI}_{590}$, indicating a wider threshold between adequate and inadequate $\mathrm{N}$ levels for sensor-determined $\mathrm{CI}_{590}$ values compared with the $\mathrm{NDVI}_{590}$. Our findings are consistent with those of Gitelson et al. (2005), who also found that $\mathrm{CI}_{\text {green }}\left(\mathrm{CI}_{590}\right.$ in our study) was more sensitive than green $\mathrm{NDVI}\left(\mathrm{NDVI}_{590}\right.$ in this study) in detecting variation in canopy chlorophyll content at moderate-to-high crop biomass (LAI values exceeding 2). These results can be attributed to the nonlinear relationship that exists between 


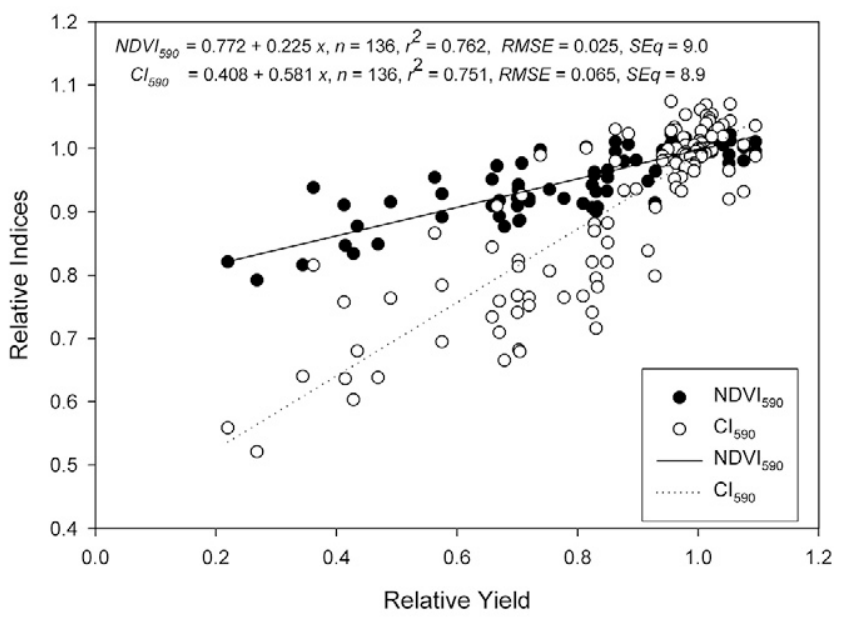

Fig. 7. Linear relationships between variation in relative grain yield and relative values for two sensor-determined vegetation indices (NDVI ${ }_{590}$, normalized difference vegetation index; $\mathrm{Cl}_{590}$, chlorophyll index) collected on two vegetative growth stages (VII and VI5) for corn receiving varying amounts of $\mathbf{N}$ applied at planting during the $\mathbf{2 0 0 5}$ growing season at the MSEA I and 3 sites located near Shelton, NE. Other parameters provided include linear regression equation, sample number $(n)$ coefficient of determination $\left(r^{2}\right)$, RMSE, and sensitivity equivalent (SEq); SEq = slope/RMSE).

$\mathrm{NDVI}_{590}$ and canopy chlorophyll content, with $\mathrm{NDVI}_{590}$ values saturating at high canopy densities; whereas $\mathrm{CI}_{590}$ values do not saturate at high vegetation fractions (Vina and Gitelson, 2005).

The same methods used for assessing the relationships between CM readings vs. vegetation indices were also used to determine differences between indices in ability to distinguish yield variation, except only at-planting $\mathrm{N}$ treatments were used at the MSEA 1 and 3 sites. This was done to avoid the confounding effects on yield from in-season $\mathrm{N}$ applications. Unlike the CM associations, the $r^{2}$ values for the two yield associations were similar (Fig. 7). Although ranking of slope values for the two yield relationships was similar to those for the CM associations (slope of $\mathrm{CI}_{590}>\mathrm{NDVI}_{590}$ ), the RMSE value was higher for the $\mathrm{CI}_{590}$ compared with $\mathrm{NDVI}_{590}$. Consequently, the computed SEq values were similar for both yield relationships (Fig. 7). Thus, unlike for the CM associations, there was no sensitivity difference between vegetation indices in ability to distinguish yield variation. Nonetheless, our results still suggest that the $\mathrm{CI}_{590}$ is better suited than $\mathrm{NDVI}_{590}$ for directing spatially variable $\mathrm{N}$ applications, because $\mathrm{CI}_{590}$ is more sensitive than $\mathrm{NDVI}_{590}$ in assessing variation in canopy greenness during vegetative growth (Fig. 5 and 6) when in-season applications are advocated (Shanahan et al., 2008).

\section{CONCLUSIONS}

Results from this study showed that the two sensor-determined vegetation indices $\left(\mathrm{NDVI}_{590}\right.$ and $\mathrm{CI}_{590}$ ) were more highly associated with CM readings during vegetative growth than during reproductive growth, which was attributed to the inability of the sensor to detect canopy variation due to interference from tassels present during reproductive growth. Because sensor-determined $\mathrm{CI}_{590}$ values were found to be more sensitive than $\mathrm{NDVI}_{590}$ in assessing canopy $\mathrm{N}$ status and indices were equally sensitive in assessing yield potential, we con- clude that sensor readings acquired during vegetative growth and expressed as $\mathrm{CI}_{590}$ would have the greatest potential for assessing canopy $\mathrm{N}$ content and directing spatially variable in-season $\mathrm{N}$ applications. However, first it will be necessary to validate our results in a wider range of soils, climate and geographical conditions, and develop algorithms for translating sensor readings into appropriate $\mathrm{N}$ fertilizer application rates.

\section{ACKNOWLEDGMENTS}

This work was supported in part by the project Thematic Soil Mapping and Crop-Based Strategies for Site-Specific Management jointly funded by USDA and NASA under the Initiative for Future Agriculture and Food Systems (IFAFS) program on Application of Geospatial and Precision Technologies (AGPT).

\section{REFERENCES}

Andrade, F.H., and P.E. Abbate. 2005. Response of maize and soybean to variability in stand uniformity. Agron. J. 97:1263-1269.

Baret, F., G. Guyot, and D.J. Major. 1989. TSAVI: A vegetation index which minimizes soil brightness effects on LAI and APAR estimation. p. 1355-1358 In Proc. 12th Canadian Symp. on Remote Sensing, IGARRS'90, Vancouver, BC, Canada. 10-14 July, 1989. Geoscience and Remote Sensing Soc. of Inst. of Electrical and Electronics Engineers, Piscataway, NJ.

Bhatti, A.U., D.J. Mulla, and B.E. Frazier. 1991. Estimation of soil properties and wheat yields on complex eroded hills using geostatistics and Thematic Mapper images. Remote Sens. Environ. 37:181-191.

Blackmer, T.M., and J.S. Schepers. 1994. Techniques for monitoring crop nitrogen status in corn. Commun. Soil Sci. Plant Anal. 25:1791-1800.

Blackmer, T.M., and J.S. Schepers. 1995. Use of chlorophyll meter to monitor nitrogen status and schedule fertigation for corn. J. Prod. Agric. $8: 56-60$.

Blackmer, T.M., J.S. Schepers, and M.F. Vigil. 1993. Chlorophyll meter readings in corn as affected by plant spacing. Commun. Soil Sci. Plant Anal. 24:2507-2516.

Boedhram, N., T.J. Arkebauer, and W.D. Batchelor. 2001. Season-long characterization of vertical distribution of leaf area in corn. Agron. J. 93:1235-1242.

Cassman, K.G., A. Dobermann, and D.T. Walters. 2002. Agroecosystems, nitrogen-use efficiency, and nitrogen management. Ambio 31:132-140.

Chapman, S.C., and H.J. Barreto. 1997. Using a chlorophyll meter to estimate specific leaf nitrogen of tropical maize during vegetative growth. Agron. J. 89:557-562.

Drouet, J.L., and R. Bonhomme. 1999. Do variations in local leaf irradiance explain changes to leaf nitrogen within row maize canopies? Ann. Bot. 84:61-69.

Gitelson, A., Y. Kaufman, and M. Merzlyak. 1996. Use of a green channel in remote sensing of global vegetation from EOS-MODIS. Remote Sens. Environ. 58:289-298.

Gitelson, A.A., A. Viña, T.J. Arkebauer, D.C. Rundquist, G. Keydan, and B. Leavitt. 2003. Remote estimation of leaf area index and green leaf biomass in maize canopies. Geophys. Res. Lett., 30(5), 1248, doi:10.1029/2002GL016450, 2003.

Gitelson, A.A., A. Viña, D.C. Rundquist, V. Ciganda, and T.J. Arkebauer. 2005. Remote estimation of canopy chlorophyll content in crops. Geophys. Res. Lett. 32:L08403 doi:10.1029/2005GL022688.

Hawkins, J.A., J.E. Sawyer, D.W. Barker, and J.P. Lundvall. 2007. Using relative chlorophyll meter values to determine nitrogen application rates for corn. Agron. J. 99:1034-1040.

Holland, K.H., J.S. Schepers, J.F. Shanahan, and G.L. Horst. 2004. Plant canopy sensor with modulated polychromatic light source. In Proc. of 7th Int. Conf. on Precision Agric., Minneapolis, MN. 25-28 July 2004. [CD-ROM]. Univ. of Minnesota, Minneapolis.

Huete, A.R. 1988. A soil-adjusted vegetation index (SAVI). Remote Sens. Environ. 25:295-309.

Jordan, C.F. 1969. Derivation of leaf area index from quality of light on the forest floor. Ecology 50:663-666.

Littel, R.C., G.A. Miliken, W.W. Stroup, and R.D. Wolfinger. 1996. SAS systems for mixed models. SAS Institute, Cary, NC. 
Liu, W., M. Tollenaar, G. Stewart, and W. Deen. 2004. Impact of planter type, planting speed, and tillage on stand uniformity and yield of corn. Agron. J. 96:1668-1672.

Lory, J.A., and P.C. Scharf. 2003. Yield goal versus delta yield for predicting fertilizer nitrogen need in corn. Agron. J. 95:994-999.

Mamo, M., G.L. Malzer, D.J. Mulla, D.R. Huggins, and J. Strock. 2003. Spatial and temporal variation in economically optimum nitrogen rate for corn. Agron. J. 95:958-964.

Markwell,J.,J.C. Osterman, and J.L. Mitchell. 1995. Calibration of the Minolta SPAD-502 leaf chlorophyll meter. Photosynth. Res. 46:467-472.

McMaster, G.S., and W.W. Wilhelm. 1997. Growing degree-days: One equation, two interpretations. Agric. For. Meteorol. 87:291-300.

Mullen, R.W., K.W. Freeman, W.R. Raun, G.V. Johnson, M.L. Stone, and J.B. Solie. 2003. Identifying an in-season response index and the potential to increase wheat yield with nitrogen. Agron. J. 95:347-351.

Osaki, M., M. Iyoda, and T. Tadano. 1995a. Ontogenic changes in the contents of ribulose-1, 5-biphosphate carboxylase/oxygenase, phosphoenolpyruvate carboxylase, and chlorophyll in individual leaves of maize. Soil Sci. Plant Nutr. 41:285-293.

Osaki, M., M. Iyoda, and T. Tadano. 1995b. Effect of nitrogen application and sink manipulation on the contents of ribulose-1, 5-biphosphate carboxylase/oxygenase, phosphoenolpyruvate carboxylase, and chlorophyll in leaves of maize during maturation stage. Soil Sci. Plant Nutr. 41:295-303.

Piekielek, W.P., and R.H. Fox. 1992. Use of a chlorophyll meter to predict sidedress nitrogen requirements for maize. Agron. J. 84:59-65.

Raun, W.R., and G.V. Johnson. 1999. Improving nitrogen use efficiency for cereal production. Agron. J. 91:357-363.

Raun, W.R., J.B. Solie, G.V. Johnson, M.L. Stone, R.W. Mullen, K.W. Freeman, W.E. Thomason, and E.V. Lukina. 2002. Improving nitrogen use efficiency in cereal grain production with optical sensing and variable rate application. Agron. J. 94:815-820.

Ritchie, S.W., J.J. Hanway, and G.O. Benson. 1997. How a corn plant develops. Spec. Rep. 48 (rev.). Iowa State Univ. Coop. Ext. Serv. Ames.

Rondeaux, G., M. Steven, and F. Baret. 1996. Optimization of soil-adjusted vegetation indices. Remote Sens. Environ. 55:95-107.

Rouse, J.W., Jr., R.H. Haas, J.A. Schell, and D.W. Deering. 1974. Monitoring vegetation systems in the Great Plains with ERTS. p. 309-317. In Third ERTS-1 Symp., Washington, DC. 10-14 Dec. 1973. NASA, Washington, DC.
Scharf, P.C., S.M. Brouder, and R.G. Hoeft. 2006. Chlorophyll meter readings can predict nitrogen need and yield response of corn in the north-central USA. Agron. J. 98:655-665.

Scharf, P.C., N.R. Kitchen, K.A. Sudduth, J.G. Davis, V.C. Hubbard, and J.A. Lory. 2005. Field-scale variability in optimal nitrogen fertilizer rate for corn. Agron. J. 97:452-461.

Schepers, J.S. 1994. New diagnostic tools for tissue testing. Commun. Soil Sci. Plant Anal. 25:817-826

Schepers, J.S., D.D. Francis, M. Vigil, and F.E. Below. 1992. Comparison of corn leaf nitrogen concentration and chlorophyll meter readings. Commun. Soil Sci. Plant Anal. 23:2173-2187.

Shanahan, J.F., K. Holland, J.S. Schepers, D.D. Francis, M.R. Schlemmer, and R. Caldwell. 2003. Use of crop reflectance sensors to assess corn leaf chlorophyll content. p. 135-150. In Digital imaging and spectral techniques: Applications to precision agriculture and crop physiology. ASA Spec. Publ. 66. ASA, Madison, WI.

Shanahan, J.F., N.R. Kitchen, W.R. Raun, and J.S. Schepers. 2008. Responsive in-season nitrogen management for cereals. Comput. Electron. Agric. 61:51-62.

Shanahan, J.F., J.S. Schepers, D.D. Francis, G.E. Varvel, W.W. Wilhelm, J.M. Tringe, M.S. Schlemmer, and D.J. Major. 2001. Use of remote sensing imagery to estimate corn grain yield. Agron. J. 93:583-589.

Shapiro, C.A., J.S. Schepers, D.D. Francis, and J.F. Shanahan. 2006. Using a chlorophyll meter to improve N management. Neb Guide G1632. Coop. Ext. Serv., Univ. of Nebraska, Lincoln.

Solari, F. 2006. Developing a crop based strategy for on-the-go nitrogen management in irrigated cornfields. Ph.D. diss. AAT 3216347. Univ. of Nebraska, Lincoln.

Varvel, G.E., J.S. Schepers, and D.D. Francis. 1997. Ability for in season correction of nitrogen deficiency in corn using chlorophyll meters. Soil Sci. Soc. Am. J. 61:1233-1239.

Varvel, G.E., W.W. Wilhelm, J.F. Shanahan, and J.S. Schepers. 2007. An algorithm for corn nitrogen recommendations using a chlorophyll meter based sufficiency index. Agron. J. 99:701-706.

Vina, A., and A.A. Gitelson. 2005. New developments in the remote estimation of the fraction of absorbed photosyntetically active radiation in crops. Geophys. Res. Lett. 32:L17403 doi:10.1029/2005GL023647.

Vina, A., A.A. Gitelson, D.C. Rundquist, G. Keydan, B. Leavitt, and J. Schepers. 2004. Monitoring maize (Zea mays L.) phenology with remote sensing. Agron. J. 96:1139-1147. 